\title{
Lissencephaly: Clinical and neuroimaging features in children
}

\author{
Nathaly S. Lapo-Córdova*, Matilde Ruiz-García, and Blanca G. Hernández-Antúnez \\ Department of Pediatric Neurology, National Institute of Pediatrics, Mexico City, Mexico
}

\begin{abstract}
Background: The spectrum of lissencephaly (LIS) corresponds to a group of serious brain malformations in the cortex caused by a failure in neuronal migration. The spectrum includes agyria, pachygyria and subcortical band heterotopia (SBH). It has generally been divided into two categories: classic lissencephaly or type I, and cobblestone lissencephaly or type II. Objective: The objective of the study was to describe clinical, neuroimaging, and neurophysiological features of pediatric patients with lissencephaly (LIS) type I. Methods: Retrospective study of children with the diagnosis of LIS, who were admitted to the National Institute of Pediatrics in Mexico City from January 2009 to December 2019. Results: We included a total of 22 patients, 15 (68\%) were male. Age at diagnosis: 4 (18\%) children under 1 month due to ventricular dilation on ultrasound and epileptic spasms; 13 (59\%) children of 1 month-1 year due to microcephaly, drug-resistant epilepsy, and neurodevelopmental delay; 5 (22\%) children over 1 year. Regarding etiology: 6 cases were due to cytomegalovirus, 1 to Zika, and 1 to microdeletion diagnosed as Miller-Dieker syndrome. All (100\%) had neurodevelopmental delay, 19 (86\%) intellectual disability. Epilepsy was found in 19 (86\%), of these 6 had epileptic spasms, 7 had West syndrome, and 5 evolved to Lennox-Gastaut. Drug-resistant epilepsy was present in 17 (77\%) patients. Regarding comorbidities: 15 (68\%) had gastroesophageal reflux disease and 14 (63\%) had recurrent pneumonia. Regarding neuroimaging findings, paquigiria was present in 9 (41\%) children. Two children died, they had diffuse agyria. Conclusions: LIS type I includes pathologies with a poor prognosis, manifested predominantly in the $1^{\text {st }}$ year of life. All patients have delayed psychomotor development, refractory epilepsy and were associated with different comorbidities. Genetic and neuroimaging studies are important to make an accurate diagnosis, predict evolution, offer genetic counseling, and palliative treatment.
\end{abstract}

Key words: Lissencephaly. Pachygyria. Agyria. Children.

\section{Lisencefalia: características clínicas y de neuroimagen en niños}

\section{Resumen}

Antecedentes: El espectro de lisencefalia (LIS) corresponde a un grupo de graves malformaciones cerebrales en la corteza causadas por un fallo en la migración neuronal. El espectro incluye agiria, paquigiria y heterotopía de banda subcortical (SBH). Generalmente se ha dividido en dos categorías: lisencefalia clásica o tipo I y lisencefalia en empedrado o tipo II. Objetivo: Describir las características clínicas, neuroimagen y neurofisiológicas de pacientes pediátricos con Lisencefalia tipo I. Métodos: Estudio retrospectivo y descriptivo de pacientes con diagnóstico de lisencefalia atendidos en el Servicio de Neurología Pediátrica del Instituto Nacional de Pediatría, en la Ciudad de México, de enero de 2009 a diciembre de 2019. Resultados: Incluimos un total de 22 pacientes, 15 (68\%) eran hombres. Edad al diagnóstico: período neonatal 4 (18\%) por

\section{Correspondence:}

*Nathaly S. Lapo-Córdova

E-mail: mdnathalylapoc@gmail.com
Available online: 07-07-2021

Rev Mex Neuroci. 2021;22(4):134-140 www.revmexneurociencia.com (http://creativecommons.org/licenses/by-nc-nd/4.0/). 
dilatación ventricular en ultrasonido, Zika materno y espasmos epilépticos; de 1 mes a 1 año: 13 (59\%) por microcefalia, epilepsia fármaco resistente y retraso del neurodesarrollo y mayores de 1 año: 5 (22\%) niños. Etiología: 6 por Citomegalovirus, 1 por Zika y 1 microdeleción con síndrome de Miller Dieker. Todos tuvieron retraso del neurodesarrollo, 19 con discapacidad intelectual (3 pacientes < 4 años). Epilepsia en 19 (86\%), 6 tuvieron espasmos epilépticos, 7 Síndrome de West, 5 evolucionaron a Lennox Gastaut. Epilepsia fármaco resistente en 17 (77\%). Comorbilidades: 14 (63\%) neumonías a repetición y 15 (68\%) con enfermedad por reflujo gastroesofágico. Paquigiria en 9 (41\%) niños. Dos niños murieron, tenían agiria difusa. Conclusión: Lisencefalia tipo I incluye patologías de mal pronóstico, que se manifiesta predominantemente en el primer año de vida. Todos los pacientes tienen retraso en el desarrollo psicomotor, epilepsia refractaria y se asocian a diferentes comorbilidades. Es importante el estudio genético y neuroimagen de alta resolución para realizar un diagnóstico preciso, predecir evolución, ofrecer consejo genético y tratamiento paliativo.

Palabras clave: Lisencefalia. Paquigiria. Agiria. Niños

\section{Introduction}

The spectrum of lissencephaly (LIS) corresponds to a group of serious brain malformations caused by a failure in neuronal migration. LIS, a term introduced by Owen Richard in 1868, comes from the Greek words "lissos" means smooth or soft and "enkephalos" means brain, it is a descriptive term. This term applied to malformations with abnormal formation of the cerebral convolutions, characterized by a smooth brain surface, intellectual disability, and seizures ${ }^{1,2}$.

The spectrum of LIS includes agyria (complete absence of cerebral convolutions), pachygyria (from the Greek "paqui" ( $\pi \alpha \chi v \varsigma$ ) means thick or broad, it is a malformation with wide cerebral gyri $)^{3-5}$, and subcortical band heterotopia (SBH) (also called double cortex, consists of smooth layers of gray matter that frequently follow the curvature of the overlying cortex $)^{6}$.

There are several forms of classification, but the most used is type I and type II LIS?. Type I or classic LIS in which it has four cell layers in the cortex, it can present in two forms such as isolated LIS and Miller-Dieker syndrome (MDS) ${ }^{8}$. Type II or cobblestone LIS in which the cerebral cortex is highly unstructured presents in three syndromes: Walker-Warburg syndrome, muscleeye-brain disease, and Fukuyama congenital muscular dystrophy ${ }^{9,10}$.

Osborn et al. ${ }^{11}$ estimated that the prevalence of LIS is approximately 1-4:100,000 newborns. Three genes are associated with classical LIS: LIS1, doublecortin (DCX), and TUBA1 $A^{12}$. Likewise, some studies report association with viral infections.

Clinically, infants present marked psychomotor developmental delay, severe epileptic encephalopathy drug refractory, and some cases facial dysmorphias associated a specific genetic syndromes ${ }^{13}$. Magnetic resonance imaging (MRI) has become an important supplement evaluation and classification.
Although the overall incidence of LIS is rare, its comorbidities are serious, affecting neurodevelopment, causing a degree of disability, and impairing their quality of life and vital prognosis. The aim of our study was to describe clinical, neuroimaging, and neurophysiological features of pediatric patients with LIS type I attended at the National Institute of Pediatrics in Mexico City.

\section{Methods}

This was a single-center retrospective study of pediatric patients ( $<18$ years) with a diagnosis of LIS admitted to the National Pediatrics Institute from January 2009 to July 2019. We included patients with MRI showing structural alteration of the cerebral cortex compatible with the classic LIS included SBH and patients with sufficient clinical information and electroencephalograms (EEG) to be classified as LIS, patients with electroencephalograms (EEG) to be classified as LIS type I, and patients with sufficient clinical information. We excluded patients with another abnormal neuronal migration such as: cobblestone LIS, complex or congenital muscular dystrophy and schizencephaly, or with incomplete information in medical records. The local ethics committee approved this protocol.

We recorded demographic and clinical data as well imaging, genetic, and neurophysiological studies of the patients. Epileptic seizures were classified according to the International League Against Epilepsy 2017 guidelines. Drug-resistant epilepsy was defined as seizures occurring despite the use of two antiepileptic drugs (AEDs) at appropriate doses.

EEG patterns were classified according to the patterns described by Hakamada et al. ${ }^{14}$, recognized since 1979. This classification shows three unique EEG patterns: Grades I, II, and III.

The features observed in brain MRI were classified using the Grading System for Classical LIS and SBH, modified by Dobyns ${ }^{15}$. This system grades the 
Table 1. Grading system for classic lissencephaly and $\mathrm{SBH}$

\begin{tabular}{|c|c|c|c|}
\hline Grade & $\begin{array}{l}\text { Description of } \\
\text { cortical malformation }\end{array}$ & \multicolumn{2}{|l|}{ Gradient } \\
\hline 1 & Diffuse agyria & & $1 a=p^{*}$ \\
\hline 2 & $\begin{array}{l}\text { Diffuse agyria with a } \\
\text { few shallow sulci }\end{array}$ & $\begin{array}{l}\text { 2a: over frontal } \\
\text { and temporal } \\
\text { poles } \\
\text { 2b: over occipital } \\
\text { poles }\end{array}$ & $\begin{array}{l}2 p>a \\
2 a>p\end{array}$ \\
\hline 3 & $\begin{array}{l}\text { Mixed agyria and } \\
\text { pachygyria }\end{array}$ & $\begin{array}{l}\text { 3a: frontal } \\
\text { pachygyria and } \\
\text { posterior agyria } \\
\text { 3b: frontal agyria } \\
\text { and posterior } \\
\text { pachygyria }\end{array}$ & $\begin{array}{l}3 p>a \\
3 a>p\end{array}$ \\
\hline 4 & $\begin{array}{l}\text { Diffuse or partial } \\
\text { pachygyria only }\end{array}$ & $\begin{array}{l}\text { 4a: greater } \\
\text { posterior than } \\
\text { anterior } \\
\text { pachygyria } \\
\text { 4b: greater } \\
\text { anterior than } \\
\text { posterior } \\
\text { pachygyria }\end{array}$ & $\begin{array}{l}4 p>a \\
4 a>p\end{array}$ \\
\hline 5 & $\begin{array}{l}\text { Mixed pachygyria } \\
\text { and SBH }\end{array}$ & $\begin{array}{l}\text { 5a: frontal SBH } \\
\text { and posterior } \\
\text { pachygyria } \\
5 \text { b: frontal } \\
\text { pachygyria and } \\
\text { posterior SBH }\end{array}$ & $\begin{aligned} 5 p & >a^{* *} \\
5 a & >p\end{aligned}$ \\
\hline 6 & $\begin{array}{l}\text { Subcortical band } \\
\text { heterotopia only }\end{array}$ & $\begin{array}{l}\text { 6a: SBH posterior } \\
\text { predominance } \\
\text { 6b: SBH anterior } \\
\text { predominance }\end{array}$ & $\begin{array}{l}6 p>a \\
6 a>p\end{array}$ \\
\hline
\end{tabular}

Modified from Dobyns and Truwit (1995) ${ }^{15}$. Grades 1-6 denote the overall severity of the lissencephaly seen on neuroimaging. $P>a$ means more severe posteriorly. $a>p$ means more severe anteriorly.

* With severe Grade 1 lissencephaly, it is difficult to determine if a gradient is present.

**The reverse $(5 p>a)$ has not been observed.

SBH: subcortical band heterotopia.

neuroradiological appearance of LIS in 6-level based on the severity and anterior-posterior gradient of the abnormalities, from severe Grade 1 (complete agyria) to mild Grade 6 (SBH only) (Table 1).

We used descriptive statistics, frequencies and proportions were calculated for categorical data, and measures of central tendency (mean) were calculated for continuous data.

\section{Results}

A total of 22 patients with LIS type 1 were included. Fifteen were male $(68 \%)$ and 7 females $(32 \%)$. Their
Table 2. Clinical and paraclinical features of children with lissencephaly

\begin{tabular}{|c|c|}
\hline Variable & $n=22$ \\
\hline Age (years), median (range) & $9.3(3-16)$ \\
\hline $\begin{array}{l}\text { Sex } \\
\quad \text { Male, n (\%) } \\
\text { Female, n (\%) }\end{array}$ & $\begin{array}{c}15(68) \\
7(32)\end{array}$ \\
\hline $\begin{array}{l}\text { Age at onset } \\
<1 \text { month old, } \mathrm{n}(\%) \\
1 \text { month-1 year old, } \mathrm{n}(\%) \\
\text { Older than } 1 \text { year old, } \mathrm{n}(\%)\end{array}$ & $\begin{array}{c}4(18) \\
13(59) \\
5(22)\end{array}$ \\
\hline $\begin{array}{l}\text { History of } \\
\text { Epilepsy, n (\%) } \\
\text { Threatened abortion, n (\%) } \\
\text { Consanguinity, n (\%) }\end{array}$ & $\begin{array}{l}8(36) \\
7(31) \\
3(13)\end{array}$ \\
\hline $\begin{array}{l}\text { Etiology } \\
\text { Unidentified, n (\%) } \\
\text { Cytomegalovirus, n (\%) } \\
\text { Zika, n (\%) } \\
\text { Microdeletion, n (\%) }\end{array}$ & $\begin{array}{l}14(64) \\
6(27) \\
1(4.5) \\
1(4.5)\end{array}$ \\
\hline $\begin{array}{l}\text { Clinical findings } \\
\text { Neurodevelopmental delay, n (\%) } \\
\text { Intellectual disability, n (\%) } \\
\text { Epilepsy, } \mathrm{n}(\%) \\
\text { Hypertonia, } \mathrm{n}(\%) \\
\text { Microcephaly, } \mathrm{n}(\%) \\
\text { Low weight for age, } \mathrm{n}(\%) \\
\text { Facial dysmorphism, } \mathrm{n}(\%) \\
\text { Spastic quadriparesis, } \mathrm{n}(\%) \\
\text { Hypotonia, } \mathrm{n}(\%) \\
\text { Macrocephaly, } \mathrm{n}(\%) \\
\text { Miller-Dieker syndrome, } \mathrm{n}(\%)\end{array}$ & $\begin{array}{c}22(100) \\
19(86) \\
19(86) \\
18(81) \\
15(68) \\
14(63) \\
11(50) \\
8(36) \\
4(18) \\
2(9) \\
1(4.5)\end{array}$ \\
\hline $\begin{array}{l}\text { Genetic studies } \\
\text { Normal karyotype, n (\%) } \\
\text { Normal FISH study 17p13.3 (LIS1 locus), n (\%) } \\
\text { Microdeletion in FISH study 17p13.3 } \\
\text { (LIS1 locus), n (\%) }\end{array}$ & $\begin{array}{c}13(59) \\
6(27) \\
1(5)\end{array}$ \\
\hline
\end{tabular}

FISH: fluorescence in situ hybridization.

mean age was 9.3 years with a range of 3-16 years of age. Two patients died at the $4^{\text {th }}$ and $5^{\text {th }}$ years of age, respectively, due to pneumonia. Regarding genetic studies, $13(59 \%)$ children had a normal karyotype of these only seven children were realized the test fluorescence in situ hybridization (FISH). Only one child was found with microdeletions of chromosome 17p13.3, this was diagnosed with MDS. Of the total of patients, only seven patients had toxoplasma, rubella, cytomegalovirus (CMV) and herpes simplex virus (TORCH) profile test and of these six were positive for CMV (Table 2).

Regarding clinical presentation symptoms in table 2, neurodevelopmental delay was present in all patients. Intellectual disability was reported in 19 (86\%) children, 
Table 3. Epilepsy features and EEG patterns in children with lissencephaly

\begin{tabular}{|c|c|}
\hline Variable & $n=22$ \\
\hline $\begin{array}{l}\text { Age at epilepsy onset } \\
\text { Age (month), median (range) }\end{array}$ & $\begin{array}{c}8 \text { months } \\
\text { (7 days-2 years) }\end{array}$ \\
\hline $\begin{array}{l}\text { Epileptic syndromes } \\
\text { West syndrome, } \mathrm{n}(\%) \\
\text { Lennox-Gastaut syndrome, n (\%) }\end{array}$ & $\begin{array}{l}6(32) \\
5(26)\end{array}$ \\
\hline $\begin{array}{l}\text { Non-syndromic epilepsy } \\
\text { Epileptic spasms, } \mathrm{n}(\%) \\
\text { Focal motor seizures, } \mathrm{n}(\%) \\
\text { Generalized tonic-clonic seizure, n (\%) } \\
\text { Epileptic status } \\
\text { Drug-resistant epilepsy }\end{array}$ & $\begin{array}{c}6(32) \\
7(37) \\
6(32) \\
10(52) \\
17(89 \%)\end{array}$ \\
\hline $\begin{array}{l}\text { EEG patterns } \\
\text { Grade I, n (\%) } \\
\text { Grade II, n (\%) } \\
\text { Grade III, n (\%) }\end{array}$ & $\begin{array}{l}8(42) \\
6(32) \\
5(31)\end{array}$ \\
\hline $\begin{array}{l}\text { Other EEG findings } \\
\text { Generalized background slowing, } \mathrm{n}(\%) \\
\text { Asymmetric pattern, } \mathrm{n}(\%) \\
\text { Hypsarrhythmia, } \mathrm{n}(\%-) \\
\text { Burst suppression, } \mathrm{n}(\%) \\
\text { Generalized spike-slow wave discharges } \\
\text { of } 1.5-2.5 \mathrm{~Hz}, \mathrm{n}(\%)\end{array}$ & $\begin{array}{l}15(78) \\
3(15) \\
6(32) \\
1(4) \\
5(31)\end{array}$ \\
\hline
\end{tabular}

EEG: electroencephalogram.

this due to three patients was under 5 years of age and could not be classified that way. Intellectual disability was determined using the Wechsler Intelligence Scale in Children-IV 2003 for children of 6-16 years. Mild intellectual disability was found in $6(27 \%)$, moderate in 3 $(14 \%)$, severe in $8(36 \%)$, and deep in $2(9 \%)$ children. Facial dysmorphia was founded in $11(50 \%)$ patients, among the findings were downward oblique palpebral fissures, epicanthus, long philtrum, hypertelorism, depressed nasal bridge, and high palate. Other findings not discussed in table 2 were clinodactyly, strabismus, cryptorchidism, scoliosis, clubfoot, and valgus foot. We founded that the four children with hypotonia in the $1^{\text {st }}$ year, later developed hypertonia with spasticity of the limbs.

Of the 22 patients in the study, 19 (86\%) had electroclinical seizures. The most frequently reported epileptic syndrome was West syndrome in $6(32 \%)$ children and of these 5 evolved to Lennox-Gastaut syndrome (Table 3).

The three EEG patterns of LIS described by Hakamada et $a .^{14}$ are described as follows: Grade I, diffuse bi-hemispheric distribution of a mixture of high-amplitude alpha $(8 \mathrm{~Hz})$ and beta $(14-16 \mathrm{~Hz})$ activity $100-200 \mu \mathrm{V}$; Grade II, diffuse bi-hemispheric distribution of slow waves from 1.5 to $2.5 \mathrm{~Hz}$ with high-amplitude acute waves up to $300 \mu \mathrm{V}$, associated with short periods of attenuation of cortical activity lasting up to $3 \mathrm{~s}$ in duration; and Grade III generalized activity with acute 1-1.5 $\mathrm{Hz}$ high-amplitude waves of $400 \mu \mathrm{V}$. We found that the 19 children had at least one of the three EEG patterns. Other electroencephalographic findings were background patterns with generalized slow activity in 15 (78\%) patients (Table 3). In all our patients, the amplitude during wakefulness ranged from 100 to $350 \mathrm{mV}$, with occasional high-amplitude discharges of up to $500 \mathrm{mV}$.

According to the classification system for LIS modified by Dobyns ${ }^{15}$, in brain MRI, the most frequent was Grade 4 correspond to pachygyria in $9(41 \%)$ children. We founded predominance of anteroposterior gradient (more severe lesion anterior). Furthermore, we found 4 (18\%) children in Grade 2, agyria with undulation of brain cortex; $3(14 \%)$ children in Grade 1, diffuse agyria; $3(14 \%)$ children in Grade 3, mixed agyria and pachygyria; 2 (9\%) children in Grade 5, pachygyria and $\mathrm{SBH}$; and only 1 $(4.5 \%)$ child in Grade 6, SBH. The two patients who died had diffuse agyria this is the most severe form. Other findings in brain MRI were agenesis of the corpus callosum, polymicrogyria, and cisterna magna (Figs. 1 and 2).

Regarding other neuroimaging studies, we founded 12 patients who had a brain computed tomography (CT), 8 patients who had a prenatal ultrasound, and 2 patients with transfontanellar ultrasound. In the brain CT studies, reports of thick cortical gyrus were founded in five children, cortical atrophy in four children, and ventriculomegaly in two children. In the prenatal ultrasound studies, reports of intrauterine growth restriction were found in four children, ventricular dilation in a single child, and in three children, the report was normal. The two children who underwent transfontanellar ultrasound were both reported with ventriculomegaly.

Regarding comorbidities, the most common was gastroesophageal reflux disease in $15(68 \%)$ patients and of these 10 patients underwent Nissen fundoplication and gastrostomy. Other comorbidities founded were recurrent pneumonia in 14 (63\%) patients, heart disease (ventricular septal defect and ductus arteriosus) reported in two children, intestinal atresia in one, and hypothyroidism in another.

\section{Discussion}

There are no exact data on the prevalence of LIS, however, studies report the overall incidence is 1 in 100,000 live births or even higher, up to 1 in 13,000 20,000 live births ${ }^{16}$. The Royal Children's Hospital in Melbourne reported 2-4 new patients with classic LIS per year, which is equivalent to an incidence of 


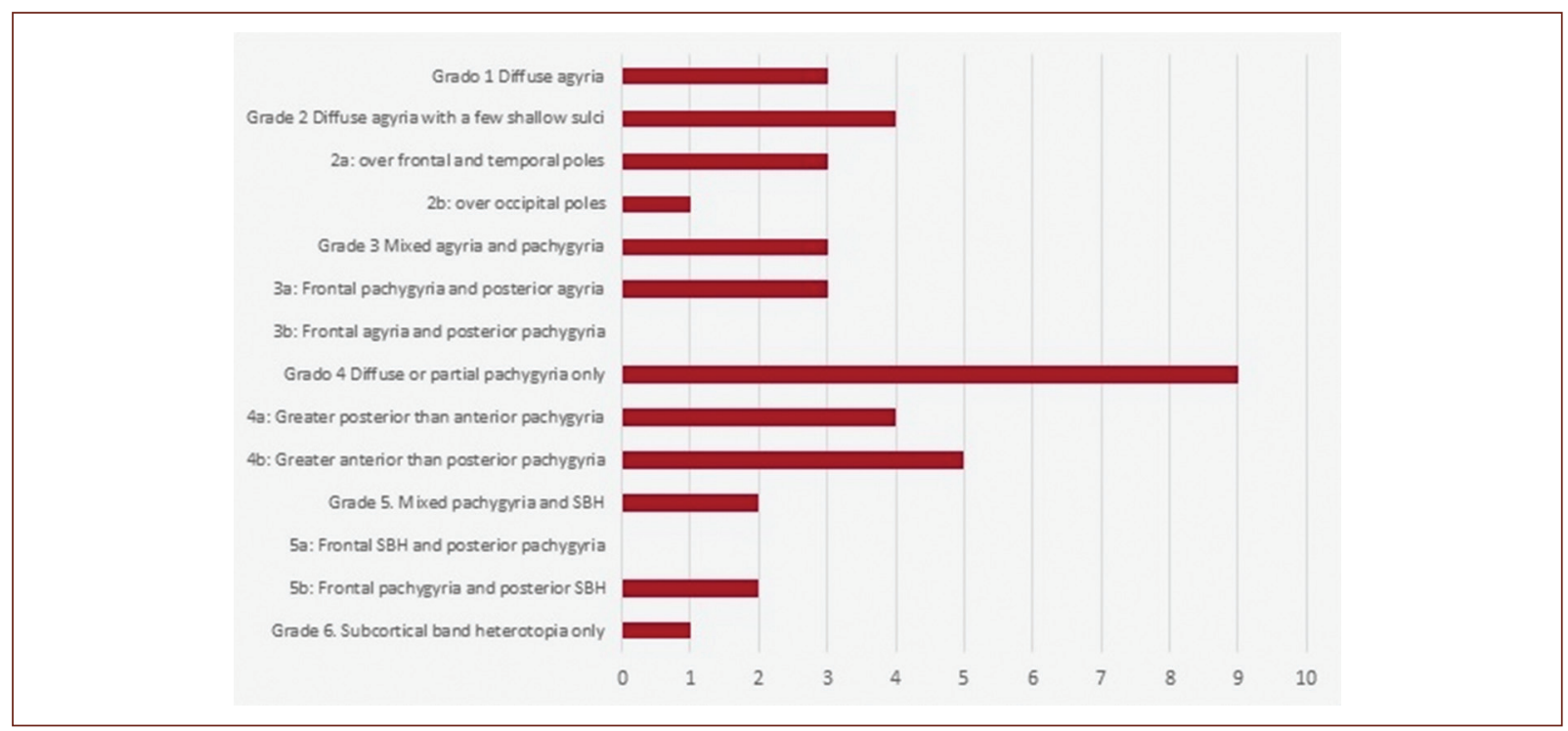

Figure 1. Classification of the brain MRI findings of children with lissencephaly according to grading system for classic lissencephaly and SBH. SBH: subcortical band heterotopia.

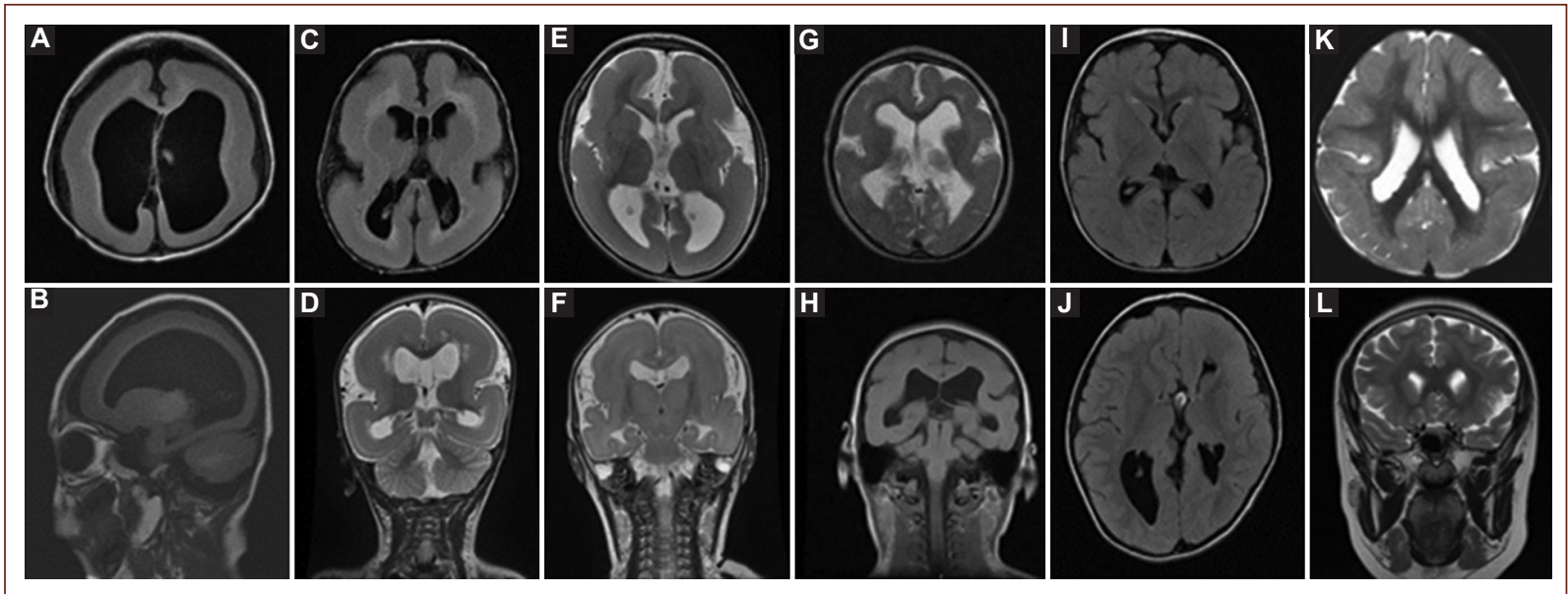

Figure 2. Brain MRI findings. A and B: agyria diffuse. C-F: agyria diffuse with few superficial undulations on frontal and temporal poles. G-H: agyria and pachygyria mixed, with frontal pachygyria and parieto-occipital agyria. I-J: partial pachygyria more severe anterior. K: more severe partial pachygyria posterior. L: heterotopia in subcortical band.

approximately 1:25,000 live births ${ }^{11}$. In our study, we reviewed clinical records in the last 10 years and we found 22 patients with classic LIS, which represents approximately 2.2 cases per year.

The cause of LIS is unknown but probably heterogeneous ${ }^{5}$. In about $80 \%$ of cases of classical LIS, a genetic cause can be found, usually an abnormality of the LIS1 or DCX gene ${ }^{17}$. In our medium, the genetic study is limited to performing a karyogram and FISH for chromosome 17 , probably due to the cost of genetic tests.
In our study, only one patient was diagnosed with MDS $^{18}$ determined by a microdeletion spanning the gene LIS1 at chromosome 17p13.3. This patient was a male of 4 years old. He presented distinctive facial features (prominent forehead, bitemporal narrowing, midface hypoplasia, upturned nares, protuberant upper lip, low seat ears, and micrognathia), as well as heart disease (interatrial communication), gastroesophageal reflux disease, and epileptic spasms. 
We were looking for a history of ingestion or exposure to drugs or toxins during pregnancy, but these data were not reported.

LIS has been associated with intrauterine viral infection, CMV is the most frequent. Early second-trimester CMV infection leads to LIS, while late second-trimester infection causes polymicrogyria ${ }^{19}$. Other pathogens involved are toxoplasmosis, rubella, herpes simplex, human immunodeficiency virus, and syphilis. In a review in Australia of 12 children with cerebral palsy and congenital CMV, the children had epilepsy, intellectual deficit and the brain malformations found were LIS, pachygyria, polymicrogyria, cerebellar hypoplasia, ventricular dilatation, and calcifications ${ }^{20}$. In our study, more than half of the patients did not have a TORCH profile test and are unknown whether there is an association with these viruses.

We report a patient who had a diagnosis of prenatal Zika infection. The patient was a girl of 2 years old. She also had microcephaly ${ }^{21}$. Her diagnosis could be determined because her mother underwent the Zika test as a screening, her mother was from Chiapas State.

Our findings show the same clinical manifestations reported in the Dobyns ${ }^{5}$ study in 1990 and 2010 categorized as (1) neurological deficits, poor feeding, hypotonia, and opisthotonos; (2) delayed neurodevelopment; or (3) seizures ${ }^{13,22,23}$.

Studies report that the frequency of epilepsy in children with LIS could be $35-85 \%$ or up to $90 \%$ this number is like those found in our study, 5,23 . The onset of epilepsy is early usually between 3 and 12 months $^{5}$, in our study, the average was 8 months. Children with LIS present several types of epilepsy. Epileptic spasms are the most frequent up to $80 \%$, which often progress to West syndrome and Lennox-Gastaut syndrome ${ }^{24}$. Focal motor seizures (myoclonic, tonic, and atonic), atypical absences, and generalized tonic-clonic seizure are also observed ${ }^{24}$. Drug-resistant epilepsy can be an independent factor contributing to mental retardation, developmental delay, and eating problems. In classical LIS, studies in mutated mice have shown specific deficiencies in cortical interneurons that use $\gamma$-aminobutyric acid (GABA) as neurotransmitter ${ }^{25}$. Therefore, GABAergic AEDs could be used. However, there is currently no FAE recommended as the gold standard in treatment. ${ }^{24,25}$.

As previously mentioned, Hakamada et al. ${ }^{14}$ determined three specific EEG patterns in LIS. Ferrier et al. ${ }^{26}$ suggested that these EEG changes may be due to the lack of sulci and denervation super sensitivity of the abnormal neurons, picked up by scalp electrodes. Gastaut et al. ${ }^{27}$ proposed that the rhythmicity and increased amplitude were related to the abnormal organization and orientation of these cortical layers.

Pattern I EEG of high-amplitude fast activity of alpha frequency intermixed with beta is most characteristic of LIS $^{28}$. Jauhari et al. ${ }^{29}$ reported that EEG pattern recognition aids in diagnosis of LIS. EEG pattern III is associated with severe developmental delay and drug-resistant epilepsy. In this study with 28 children, the EEG pattern I was the most common $14(50 \%)^{29}$. In our study, the EEG pattern I also was the most common in $8(42 \%)$ children.

Many children with LIS have bulbar difficulties that result in difficulties with feeding and respiratory function $^{23}$, as reported in our research, the most frequent comorbidities were gastroesophageal reflux and recurrent pneumonia. Furthermore, there are reports of various non-neurological abnormalities such as congenital heart disease, cataracts, duodenal atresia, renal agenesis, polydactyly or syndactyly, and cryptorchidism ${ }^{30}$.

Prenatal diagnosis of LIS, although difficult, can be suspected from 23 weeks of gestation. The abnormal features in prenatal US images at 23 weeks are ventriculomegaly and shallow Sylvian fissure ${ }^{31}$. In older gestational ages, other findings are widespread agyria, abnormal insula, corpus callosum, microcephaly, intrauterine growth restriction, and hydramnios ${ }^{32}$.

Dobyns et al. ${ }^{15}$ observed two types of patterns or gradient of severity according to brain MRI imaging findings. The first pattern is an anteroposterior gradient $(a>p)$ with greater involvement in the anterior cerebral cortex (frontal lobe). The second pattern is a posteroanterior gradient $(p>a)$ with greater involvement in the posterior cerebral cortex (parietal or occipital lobe) $)^{5,15}$. In the most severe form of LIS (complete agyria), can be difficult to differentiate the type of pattern. Di Donato et al. ${ }^{22}$ reported that the most common form of LIS was partial agyria-pachygyria that was most severe posteriorly (posteroanterior gradient) or Grade $3 a(3 p>a)$. In our study, only three children have this grade. The next most common patterns were pachygyria ${ }^{22}$. In our review, pachygyria (grade 4) was the most common.

Treatment is generally symptomatic and supportive ${ }^{33}$. The most patients used antiepileptic polytherapy that was ineffective. As previously mentioned, a large percentage of patient required gastrostomy, several had multiple hospitalizations for status epilepticus and pneumonia. Children with heart disease received cardiology treatment and some children required orthopedic management and surgery.

The prognosis depends on the severity of the malformations, some forms of LIS have a severe neurological phenotype with a markedly reduced life expectancy 
and many dies before the age of 10 years $^{33}$. For classic LIS, the mortality rate is $>50 \%$ at 10 years and few children live more than 20 years ${ }^{5,34}$. Respiratory diseases are the most common causes of comorbidities and death ${ }^{35}$. In our study, the two patients died due pneumonia and both had diffuse agyria.

\section{Conclusions}

LIS includes pathologies with a poor prognosis, manifested predominantly in the $1^{\text {st }}$ year of life. Neurodevelopmental cognitive and motor alterations are frequent and significant. All patients with LIS have neurodevelopmental delay, drug-resistant epilepsy and are associated with different comorbidities. The pattern most frequent in EEG is Grade I. In brain MRI, pachygyria is the malformation most frequent. An early diagnosis can be made with an adequate prenatal ultrasound. Our suggestions are: to recognize EEG patterns in LIS and clinical findings to facilitate the diagnosis; To consider the types of patterns or gradient of severity according to brain MRI imaging findings as a prognostic factor; To research etiology with genetic studies and testing for viral infections, (and in addition, offering genetic counseling); Diagnosing and initiating symptomatic treatment in early stages to avoid comorbidities. Finally, more studies are required to better understand and improve the treatment and outcome of this pathology.

\section{Funding}

None.

\section{Conflicts of interest}

None.

\section{Ethical disclosures}

Protection of human and animal subjects. The authors declare that no experiments were performed on humans or animals for this study.

Confidentiality of data. The authors declare that they have followed the protocols of their work center on the publication of patient data.

Right to privacy and informed consent. The authors declare that no patient data appear in this article.

\section{References}

1. Biassette, H. Hardin, B. Golden J. Lissencephaly. In: Wiley J, editor. Developmental Neuropathology. $2^{\text {nd }}$ ed. Oxford, USA: Wiley; 2018. p. 560.
2. Vélez L. Trastornos de migración neuronal. Gac Méd Méx. 2014;134:207-15.

3. Desai T, Bahri N, Salodiya H, Parmar G. MRI findings of cortical malformations in infants presenting with intractable epilepsy. Eur Soc Radiol. 2018;3214-8.

4. Ramirez D, Lammer E, Johnson C, Peterson C. Autosomal recessive frontotemporal pachygyria. Am J Med Genet. 2004;124:231-8.

5. Dobyns $\mathbf{W}$. The clinical patterns and molecular genetics of lissencephaly and subcortical band heterotopia: malformations of cortical development-genetics. Epilepsia. 2010;51:5-9.

6. Kini L, Nasrallah I, Coto C, Ferraro L, Davis K. Advanced structural multimodal imaging of a patient with subcortical band heterotopia. Epilepsia Open. 2016;1:152-5

7. Swaiman K, Finkel R, Ashwa S. Swaiman's Pediatric Neurology. $6^{\text {th }}$ ed. Minneapolis, USA: Elsevier; 2018. p. 218-25.

8. López J, Herrera L, Ramírez R, Ángeles M, Zárate P. Lisencefalia tipo 1: síndrome de miller-dieker. Rev Mex Pediatr. 1999;66:157-60.

9. Shenoy A, Markowitz J, Bonnemann C, Krishnamoorthy K, Bossler AD, Tseng B. Muscle-eye-brain disease. J Clin Neuromuscul Dis. 2010;11:124-6.

10. Angelini C, Angelini C. Fukuyama congenital muscular dystrophy: walker-warburg syndrome. Genet Neuromuscul Disord. 2017;28:107-10.

11. Osborn A, Harnsberger H, Salzman K. Diagnostic Imaging: Brain. $4^{\text {th }}$ ed. Canada: Elsevier; 2001.

12. Leventer R. Lissencephaly Type I. In: Sarnat H, editor. Malformations of the Nervous System. Netherlands: Elsevier; 2008. p. 205-18.

13. Barkovich A, Dobyns W, Guerrin R. Malformations of cortical development and epilepsy. Cold Spring Harb Perspect Med. 2015;5:47-62.

14. Hakamada S, Watanabe K, Hara K, Miyazaki S. The evolution of electroencephalographic features in lissencephaly syndrome. Brain Dev. 1979:1:277-83.

15. Dobyns W, Truwit C. Lissencephaly and other malformations of cortical development: 1995 update. Neuropediatrics. 1995;26:132-47.

16. Menascu $S$, Weinstock $A$, Faroog $O$, Hoffman $H$. EEG and neuroimaging correlations in children with lissencephaly. Seizure Eur J Epilepsy. 2013;22:189-93.

17. Fry A, Cushion T. The genetics of lissencephaly. Am J Med Genet. 2014;166:198-210.

18. Matarese C, Renaud D. Classical (Type I) lissencephaly and miller-dieker syndrome. Pediatr Neurol. 2009;40:324-5.

19. Joseph L, Kuruvilla S. Cytomegalovirus infection with lissencephaly. Indian J Pathol Microbiol. 2008;2:402-4.

20. Smithers A, Raynes C, Badawi N, Susan M, Meehan E, Gibson CS, et al. Neuroimaging findings in a series of children with cerebral palsy and congenital cytomegalovirus infection. Infect Disord Drug Targets. 2014;10:10-9.

21. Hussain A, Ali F, Latiwesh O, Hussain S. A comprehensive review of the manifestations and pathogenesis of Zika virus in neonates and adults. Cureus. 2018;10:12-8

22. Di Donato N, Chiari S, Mirzaa G, Aldinger K, Parrini E, Olds C, et al. Lissencephaly: expanded imaging and clinical classification. Am J Med Genet Part A. 2017;173:1473-88.

23. Guerrini R, Dobyns WB. Malformations of cortical development: clinical features and genetic causes. Lancet Neurol. 2014;13:710-26.

24. Herbst S, Proepper C, Geis T, Borggraefe I, Hahn A, Debus O. LIS1-associated classic lissencephaly: a retrospective, multicenter survey of the epileptogenic phenotype and response to antiepileptic drugs. Brain Dev. 2016;38:399-406.

25. Mcmanus MF, Nasrallah IM, Pancoast MM, Wynshaw-boris A, Golden JA. Lis1 is necessary for normal non-radial migration of inhibitory interneurons. Am J Pathol. 2004;16:775-84

26. Ferrier C, Aronica E, Leijten F, Spliet W, van Huffelen A, van Rijen P, et al. Electrocorticographic discharge patterns in glioneuronal tumors and focal cortical dysplasia. Epilepsia. 2006;47:1477-86.

27. Gastaut H, Pinsard N, Raybaud C, Aicardi J, Zifkin B. Lissencephaly (agyria pachygyria): clinical findings and serial EEG studies. Dev Med Child Neurol. 1987;29:167-80.

28. Arts F, Weerd D. EEG and evoked potentials in a series of 21 patients with lissencephaly Type I. Neuropediatrics. 1992;3:4-9.

29. Jauhari $P$, Farmania R, Chakrabarty B, Kumar A, Gulati S. Electrographic pattern recognition: a simple tool to predict clinical outcome in children with lissencephaly. Seizure. 2020;8:175-80.

30. Alhasan M, Mathkour M, Milburn JM. Postterm newborn with lissencephaly presented with seizure: case report and review of literature. Ochsner J. 2015;8:127-9.

31. Ghai S, Fong K, Toi A, Chitayat D, Pantazi S, Blaser S. Prenatal US and MR imaging findings of lissencephaly: review of fetal cerebral sulcal development. Radiographics. 2006;26:389-405.

32. Williams $F$, Griffiths $P$. In utero MR imaging in fetuses at high risk of lissencephaly. Br J Radiol. 2017;4:10-3.

33. Kattuoa M, Das J. Lissencephaly. In: Stat Pearls. Treasure Island, FL: Stat Pearls; 2020.

34. de Rijk-van Andel J, Arts W, Hofman A, Staal A, Niermeijer M. Epidemiology of lissencephaly Type I. Neuroepidemiology.1991;10:200-4.

35. de Wit M, de Rijk-Van A, Halley D, Poddighe P, Arts W, de Coo I, et al Long-term follow-up of Type 1 lissencephaly: survival is related to neuroimaging abnormalities. Dev Med Child Neurol. 2011;53:417-21. 